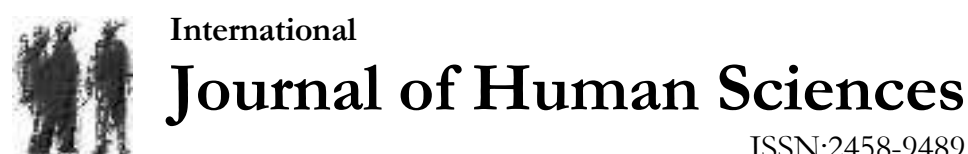

Volume 15 Issue 4 Year: 2018

\section{Do the teachers' organizational trust levels predict their school academic optimism? ${ }^{1}$}

\begin{abstract}
Aynur B. Bostanci ${ }^{2}$
Sebila Bülbü1 ${ }^{3}$

Abstract

This research was conducted to determine the relationship between teachers' organizational trust levels and academic optimism perception about their schools. The research is in relational screening model. The sample of the study consisted of 299 teachers working in primary, secondary and high schools in Uşak province. In the study, simple random sampling was employed. The data were collected by The Organizational Trust Scale and the Organizational Trust in Colleagues Scale and School Academic Optimism Scale. In the analysis of the data, arithmetic mean, one way variance analysis, Pearson Product Moment Coefficient and multiple regression analysis were used. According to the results of the study; It is observed that teachers who work in primary school and secondary schools have high levels of trust in the organization and teachers who work in high schools have a moderate level of trust in the organization. The level of teachers' trust in the administrator working in all school levels is moderate. Again teachers' perceptions about academic optimism of their schools is high in all school levels. In the research, the school academic optimism levels of primary school teachers was found higher than that of high school teachers. A significant relationship between teachers' trust in the organizational and the level of school academic optimism was found only in secondary schools. While there is a low positive relationship between the teachers' trust in the administrator and school academic optimism levels in primary school, there is a moderate positive relationship in secondary and high schools. While primary teachers' trust in the administrator does not predict school academic optimism levels; level of trust of secondary and high schools teachers to administrators predicts about school academic optimism levels of their schools.
\end{abstract}

Keywords: Trust in the organization; trust in the administrator; school academic optimism.

\section{Introduction}

Organizational trust is employees' commitment to the organization as a result of the relations within the organization formed in line with the strategies and policies of the organization and staying in the organization as a result of their integration with the aims and values of the organization. In order to create this situation, organizations need to fulfill the practices such as support of the employees, meeting the demands and needs of the employees, improving the social relations within the organization to the desired level and developing the cooperation among the employees (Demirel, 2008). Those who work in the organization are more willing to contribute to the organization when they see that they are valued and respected

\footnotetext{
1 This study presented International Congress on Science and Education 2018(ICSE2018), (23 $3^{\text {th }}$ 25 th $^{\text {tharch }}$ 2018).Afyon Kocatepe University, Turkey.

2 Assoc. Prof. Dr., Usak University, Faculty of Education, aynur.bozkurt@usak.edu.tr

${ }^{3}$ M.A., bulbulsebila@hotmail.com
} 
B. Bostanc1, A., \& Bülbül, S. (2018). Do the teachers' organizational trust levels predict their school academic optimism? Journal of Human Sciences, 15(4), 2626-2634. doi:10.14687/jhs.v15i4.5642

(Dawley, Andrews \& Bucklew, 2007; Lam \& Lau, 2012). Organizational trust can also be seen as positive expectations of the employees primary in organizational roles, relationships and experiences (Kalemci Tüzün, 2007).

In consisting organizational trust the administrators have a great responsibility. When administrators support employees and when take care of them, employees will be eager to act in a more creative, successful and organizational way (Winstanley \& Stuart-Smith, 1996; Montani, Odoardi \& Battistel, 2012). Cormeu, Ferres and Travaguone (2003) state that there is a need to develop interpersonal supportive relationships for the emergence of trust in organizations. According to them, organizational trust arises from the interaction between the administrator and the employees. At the end of the study, it was found out that the employees who work with fair and supportive relationships to their employees and the employees have more trust in their organizations and do not intend to leave. However, this relational trust is important for achieving organizational goals (Bird, Wang, Watson \& Murray, 2012). In schools, administrators should act by relying on the fact that teachers will work jointly for students, help the school to develop, and try to establish positive relationships with parents (Northfield, 2014). In order for the school to reach its goals, teachers efforts should be supported and an environment of trust should be created in school (Denig \& Quinn, 2001). In this sense, it is understood that organizational trust also affects the level of school academic optimism.

Academic optimism is described as teachers' belief of cooperating with parents and students in the process for knowledge and learning, trust their capacity to overcome difficulties and positive beliefs that students can make changes in their academic performance (Hoy and Kurz, 2008, eg: Çoban \& Demirtaş, 2011). Because teachers who have school academic optimism about their students' learning, think that their students are a unique individual, that all students can be successful if they are given the opportunity and that students and their families should be trusted and cooperated for the success of students. (Özdemir \& Kilınç, 2013). Shool academic optimism can be defined as the belief that the teachers can make a difference in the academic achievement of his/her students in school. For this, the teachers needs to focus on creating a positive and ambitious learning environment for students, with a sense of competence, a sense of trust for students and parents. In short, self-efficacy, trust and academic emphasis is a general structure (Hoy, Hoy \& Kurz, 2008, Akt: Çelik \& Gürol, 2015; Çoban \& Demirtaş, 2011). These components can be described as follows:

Self-sufficiency refers to trust in one's own resources (Yildirım \& İlhan, 2010). In recent years, although teachers face many problems that teachers have to deal with, some teachers feel more adequate. The reason for this is the self-efficacy beliefs of teachers (Rimm-Kaufman \& Sawyer, 2004, Akt: Çapri \& Kan, 2006). The trust dimension of school academic optimism enables mutual respect between teachers and students and between teachers and parents. $A$ sense of trust is the belief that teachers, students and families must cooperate to improve teaching. The academic emphasis is related to the time that the teachers devotes to teaching and the effort that the students are making to meet their learning needs. The academic emphasis, which focuses on creating an environment based on academic optimism in school and teachers' school, is an important organizational trait that supports student achievement or provides students with superior performance (Smith \& Hoy, 2007). In schools where teachers and teachers collaborate, teachers believe that their students can be successful. Significant positive relationships were found between the support culture of the school and the academic optimism of teachers (Yllmaz \& Kurşun, 2015).

The support and cooperation given to the teacher in the school provides teachers' trust in the school. The job satisfaction and optimism which depend on and support the schools of the future of the school depends on high teachers (Trace, 2016). Bryk and Schneider (2003) found a relationship between school trust and school academic efficiency. A reliable school environment makes teachers open to innovation and change, gives teachers hope and allows teachers to think 
B. Bostanc1, A., \& Bülbül, S. (2018). Do the teachers' organizational trust levels predict their school academic optimism? Journal of Human Sciences, 15(4), 2626-2634. doi:10.14687/jhs.v15i4.5642

about how to achieve a better learning environment (Bökeoğlu \& Yllmaz, 2008).According to the statements made here; It can be thought that the trust environment in the school can affect the level of school academic optimism of the teacher. Therefore, this research was conducted to determine the relationship between teachers' organizational trust levels and academic optimism for their schools. For this purpose, the following questions were searched:

1. What is the teachers' trust level in the organization and the administrator? Do teachers' trust in the organization and the administrator differ in terms of the school level they work?

2. What is the level of schools' academic optimism? Do the teachers' perceptions about academic optimism of their schools differ in terms of the school level they work?

3. Is there a relationship between teachers' organizational trust and school academic optimism perceptions?

4. Do teachers' trust in the organization and the administrator predict the school academic optimism perceptions?

\section{Method}

This part of the research includes information about the model, population, sample, data tools and analysis of the data.

\subsection{Research model}

Research is in relational screening model. In this study, the opinions of the teachers about the organizational trust levels and schools academic optimism were scanned.

\subsection{The population and sample of the research}

The population of the study consists of 3700 teachers working in primary, secondary and high schools in Uşak province. The theoretical sample size chart was used in the sample selection. Simple random sampling was conducted in the study. In this sense, 299 teachers working in Uşak Province constitute the sample of the research. The sample of the research teachers; According to the school level, 72 (24.3\%), elementary school, 88 (29.7\%) in secondary school and $122(40.5 \%)$ are working in high school.

\subsection{Data collection tools}

The data were collected by "Organizational Trust" and "Organizational Trust in Colleagues Scale" by Polat (2008) and School Academic Optimism Scale at which was adapted to Turkish by Çoban and Demirtaş (2005). The Organizational Trust Scale and the Organizational Trust in Colleagues Scale are a Likert-type scales which indicate (1 don't agree) and (5 completely agree). Organizational Trust Scale consists of 21 items. The reliability of Cronbach's Alpha Coefficient of the Organizational Trust Scale was calculated as. 96. For the purpose of this study, the reliability coefficient was calculated as 92 for the Organizational Trust Scale. Organizational Trust in Colleagues Scale consists of 16 items. Cronbach's Alpha Coefficient of this scale was determined as 94. The reliability coefficient of Organizational Trust in Colleagues Scale calculated for this research is 88. The School Academic Optimism Scale consists of 19 items and three dimensions. These dimensions are dimensions of self-efficacy, trust and academic emphasis. The scale is a 5-point Likert-type scale and is considered to be differentiated between "Strongly disagree and Strongly agree Scale. The Cronbach's Alpha Coefficient of the Academic Optimism Scale was determined as 0.85 by the researchers who adapted the scale. For this research, reliability coefficient was found as .94 .

\subsection{Analysis of data}

In order to determine whether the data obtained in the study were distributed normally, Skewness and Kurtosis values were examined for each dimension and these values were found to be between -1.5 and +1.5 values in the literature. Calculated skewness and kurtosis numbers were found to be -.272 and -.153 for organizational trust, and .198 and .118 for trust in administrator. It is calculated as .333 and -.171 for academic optimism. One-way analysis of variance, t-test, Pearson Product-Moment Coefficient and multiple regression analysis were used in the analysis of the data. Academic environment and standard deviations of teachers' trust in the organization, 
B. Bostanc1, A., \& Bülbül, S. (2018). Do the teachers' organizational trust levels predict their school academic optimism? Journal of Human Sciences, 15(4), 2626-2634. doi:10.14687/jhs.v15i4.5642

trust in the administration and academic optimism towards the perceptions of students in school levels were calculated. One-way analysis of variance (ANOVA) was used to determine whether teachers' trust in the organization, trust in the administrator, and academic optimism differ according to school levels. The TUKEY test was applied to determine the difference which was supposed to be meaningful between the groups. Again, the relationships between teachers' trust in the organization, trust in the administrator and perceptions of academic optimism were examined with the Pearson Product Moment Coefficient. Multiple regression analysis techniques were used to determine the trust of the teachers and trust in the administrators according to the school level. The significance level was taken as. 05

\section{Findings and comments}

In this part of the research, the findings obtained from the analysis of the sub-problems of the research and the comments made based on these findings are included. Table 1 below shows the results of the analysis of the variance of the teachers about trust in the organization and the in the administrator and the level of school academic optimism according to the school level.

Table 1

The results of the analysis of variance of teachers about trust in the organization, trust in the administrator and levels of school academic optimism.

\begin{tabular}{|c|c|c|c|c|c|c|}
\hline Variables & $\mathbf{N}$ & $\bar{X}$ & $\mathbf{S}$ & $\mathbf{F}$ & $\mathrm{p}$ & Difference \\
\hline \multicolumn{7}{|c|}{ Trust in the organization } \\
\hline Primary & 88 & 3.62 & 687 & \multirow{3}{*}{6,320} & \multirow{3}{*}{, 002} & \multirow{3}{*}{$\begin{array}{l}* \text { Between } \\
\text { primary and high } \\
\text { school }\end{array}$} \\
\hline Secondary & 96 & 3.41 &, 741 & & & \\
\hline High school & 112 & 3.28 &, 599 & & & \\
\hline \multicolumn{7}{|c|}{ Trust to administrator } \\
\hline Primary & 88 & 3.35 & 677 & \multirow{3}{*}{2,435} & \multirow{3}{*}{,089 } & \multirow[t]{3}{*}{ No difference } \\
\hline Secondary & 96 & 3.20 & 679 & & & \\
\hline High school & 112 & 3.15 & ,632 & & & \\
\hline \multicolumn{7}{|c|}{ School academic optimism } \\
\hline Primary & 88 & 3,69 & ,491 & \multirow{3}{*}{4,636} & \multirow{3}{*}{,010 } & \multirow{3}{*}{$\begin{array}{l}* \text { Between } \\
\text { primary and high } \\
\text { school }\end{array}$} \\
\hline Secondary & 96 & 3,54 & 650 & & & \\
\hline High school & 112 & 3,45 &, 588 & & & \\
\hline
\end{tabular}

According to Table 1, when teachers' organizational trust is examined; It is observed that teachers working in Primary school $(=3.62)$ and Secondary school $(=3.41)$ have high level of trust and high school teachers $(=3.28)$ have moderate organizational trust. It is seen that the level of trust of teachers in organization according to school levels differ. Primary school teachers' organizational trust is higher than that of high school teachers $[\mathrm{F}(2-296)=6,32 ; \mathrm{p}<0.05]$. It is seen that the level of trust of the teachers working at all school levels trust in the administrator is at medium level. It is understood that the level of trust of the teachers according to the school levels doesn't differ $[\mathrm{F}(2-296)=, 089 ; \mathrm{p}>0.05]$. The teachers' perceptions about academic optimism of their schools is high at all school levels. The academic optimism of the teachers differs in terms of the school level $[\mathrm{F}(2-296)=4.63 ; \mathrm{p}<0.05]$. According to the analysis, this difference is between high school teachers and primary school teachers. The level of academic optimism of primary school teachers is higher than that of high school teachers. Table 2 below shows the analysis of the relationships between teachers' trust in the organization, trust in the administrator and the academic optimism. 
B. Bostanc1, A., \& Bülbül, S. (2018). Do the teachers' organizational trust levels predict their school academic optimism? Journal of Human Sciences, 15(4), 2626-2634. doi:10.14687/jhs.v15i4.5642

\section{Table 2}

The results of the analysis of the relationships between teachers' trust in the organization, trust in the administrator and school academic optimism.

\begin{tabular}{llrc}
\hline School level & Variables & & $\begin{array}{c}\text { School academic } \\
\text { optimism }\end{array}$ \\
\hline Primary & Trust in organization & Pearson Correlation &, 118 \\
& Trust to administrator & Searson Correlation &, 136 \\
\cline { 2 - 4 } & Trust in organization & Sig.(2-tailed) &, $186^{*}$ \\
& & Pearson Correlation &, 042 \\
\hline Secondary & Sig.(2-tailed) &, $464^{*}$ \\
& Trust to administrator & Pearson Correlation &, 000 \\
& & Sig.(2-tailed) &, $040^{*}$ \\
nyigh school & Trust in organization & Pearson Correlation &, 180 \\
& & Sig. (2-tailed) &, 080 \\
\cline { 2 - 4 } & Trust to administrator & Pearson Correlation &, $436^{*}$ \\
& & Sig. (2-tailed) &, 000 \\
\hline
\end{tabular}

As depicted in Table 2, there is no significant relationship between the teachers' organizational trust levels and academic optimism perception towards their schools $(r=.118)$ in primary schools; There is a low level significant positive relationship between teachers' trust in administrator and school academic optimism levels $(r=.186)$. There is also moderate level significant positive relationship between secondary schools teachers' trust in the organization and school academic optimism levels $(r=.464)$ and trust in the administrator and school academic optimism levels $(r=.640)$. Finally, there is no significant correlation between the organizational trust perceptions of high school teachers and their school academic optimism levels $(r=.181)$; There is a moderate positive relationship between trust in the administrator and the school academic optimism levels $(\mathrm{r}=$.436). The following table 3 shows the results of the multiple regression analysis of whether teachers' organization trust levels predict school academic optimism in primary schools.

Table 3

The results of the multiple regression analysis of level of teachers' in the organizational trust about the predictions of their school academic optimism in primary schools.

\begin{tabular}{lccccccc}
\hline Variable & $\boldsymbol{B}$ & $\boldsymbol{S D}$ & $\boldsymbol{\beta}$ & $\mathbf{t}$ & $\mathbf{p}$ & binary & partial \\
\hline Constant & 3,276 &, 290 & & 11,284 &, 000 & & \\
\hline Trust in organization &,- 038 &, 117 &,- 053 &,- 327 &, 745 & -.035 & -.035 \\
\hline Trust to administrator &, 164 &, 118 &, 226 & 1.384 &, 170 &, 148 & \multirow{2}{*}{, 147} \\
\hline
\end{tabular}

$\mathrm{F}=1,573, \mathrm{p}>.05, \mathrm{R}=.189 \mathrm{R} 2=.036$

Table 3, it is concluded that teachers' trust in the organization and trust in the the administrator does not predict the school academic optimism levels in primary school $(\mathrm{R}=.189$, $\mathrm{R} 2=.036, \mathrm{p}>.05)$. In the following table 4 , shows the results of the multiple regression analysis of whether teachers' organizational trust levels predict academic optimism in secondary schools. 
B. Bostanc1, A., \& Bülbül, S. (2018). Do the teachers' organizational trust levels predict their school academic optimism? Journal of Human Sciences, 15(4), 2626-2634. doi:10.14687/jhs.v15i4.5642

\section{Table 4}

The results of the multiple regression analysis of level of teachers' organizational trust about the predictions of their school academic optimism in secondary school.

\begin{tabular}{lccccccc}
\hline Variable & $\boldsymbol{B}$ & $\boldsymbol{S D}$ & $\boldsymbol{\beta}$ & $\mathbf{t}$ & $\mathbf{p}$ & binary & part \\
\hline Constant & 1,469 &, 271 & & 5,442 &, 000 & & \\
\hline Trust in organization &, 088 &, 090 & .100 & .977 & .331 & .101 & 0.77 \\
\hline Trust to administrator &, 553 &, 098 & .577 & 5,642 & .000 & .505 &, 447 \\
\hline
\end{tabular}

$\mathrm{F}=33,016, \mathrm{p}<.01 \quad \mathrm{R}=644 \quad \mathrm{R} 2=.415$

As can be seen in Table 4, there is a significant relationship between teachers' trust in the administrator and school academic optimism levels $(\mathrm{R}=, 436, \mathrm{R} 2=, 19, \mathrm{p}<.05)$. Teachers' trust in the administrator explain $41 \%$ of the total variance in school academic optimism level. When the trust values of the teachers are examined, it is seen that trust in the administrator $(\beta=, 577, p$ $<.05)$ predicts their the school academic optimism levels. A one-unit increase in teachers' trust in the administartor increases the school academic optimism levels of teachers by. 58. Teachers' trust in the organization in secondary school does not predict the school academic optimism levels. In Table 5 below, the the results of the multiple regression analysis of whether teachers' in the organizational trust levels predict school academic optimism in high schools.

\section{Table 5}

The results of the multiple regression analysis of level of teachers' organizational trust about the predictions of their school academic optimism in high school.

\begin{tabular}{lccccccc}
\hline Constant & $\boldsymbol{B}$ & $\boldsymbol{S D}$ & $\boldsymbol{\beta}$ & $\mathbf{t}$ & $\mathbf{p}$ & binary & partial \\
\hline Trust in organization & 2,246 &, 512 & & 7,446 &, 000 & & \\
\hline Trust to administrator &, 010 &, 181 &,- 010 &,- 108 &, 914 &, 181 & -.010 \\
\hline Constant &, 389 &, 201 &, 440 & 4,598 &, 000 &, 436 &, 403 \\
\hline $\mathrm{F}=12,764, \mathrm{p}<.01$ & $\mathrm{R}=436$ & $\mathrm{R} 2=.19$ & & & & &
\end{tabular}

As can be seen in Table 5, there is a significant relationship between teachers' trust in the administrator and school academic optimism $(\mathrm{F}=12,764 ; \mathrm{p}<0.01)$. The teachers' trust in the administrator explain $19 \%$ of the total variance in school academic optimism. According to Beta values, it is seen that trust levels of the teachers to the administrator $(\beta=, 440, p<.05)$ predicts schools' academic optimism. One-unit increase in the teachers' trust in the administrator increases schools' academic optimism levels by .39. Again, high school teachers' organizational trust level do not predict the academic optimism of schools.

\section{Result, discussion and recommendations}

The aim of this research was to determine the relationship between teachers' organizational trust levels and academic optimism levels for their schools. Looking at the level of trust of teachers in the organization; It is observed that teachers working in primary and secondary schools have high levels of trust in the organization and that teachers who work in high schools have a moderate level of trust in the organization. The results of the study are similar to the research conducted by Polat and Celep (2008), Baş and Şentürk (2011) and Ayduğ and Ağaoğlu (2017). Özer, Demirtaş Üstüner and Cömert (2006), Çağlar (2011), Memduhoğlu and Zengin (2011), Gören and Özdemir (2015) and Adigüzel (2016) found that the level of organizational trust perceived by teachers was moderate. In addition, Baş and Şentürk (2011) found that primary teachers had positive perceptions about organizational trust in their schools. The level of trust of 
B. Bostanc1, A., \& Bülbül, S. (2018). Do the teachers' organizational trust levels predict their school academic optimism? Journal of Human Sciences, 15(4), 2626-2634. doi:10.14687/ihs.v15i4.5642

teachers in primary schools is higher than that of high school teachers. Besides, it is observed that teachers who work in all school levels have a moderate level of trust in the administrator.

Also teachers' school academic optimism levels is high in all school levels. In the studies conducted by Yılmaz and Kurşun (2015), Çoban and Demirtaş (2010) and Bostanc1, Tosun, Gidiş, and Karaca (2016), the teachers' academic optimism was found to be high. With these results, it can be said that the research has reached similar results. The academic optimism of the primary school was found higher than the high schools. This result is supported by the study of Çağlar (2013). Çağlar (2013) also found that the level of academic optimism of high schools was lower than that of secondary schools in termes of type of school. This may be due to the fact that there is a longer time for the development process in front of the pupils in schools, higher beliefs that students can learn, and more relationship between parents and teachers.

Considering the relationships between the level of trust of teachers and their school academic optimism at school levels; A significant positive moderate level relationship between teachers' trust in the organizational and the school academic optimism levels was found only in secondary schools. While there is a low significant positive relationship between the level of teacher' trust in administrator and school academic optimism levels in the primary school, there is a moderate positive relationship in secondary and high schools. As primary school teachers are at the same class most of the time, they may be creating an academic environment in their class. A significant relationship between teachers' in the organization and academic optimism was found only in secondary schools.

While primary teachers' trust in the administrator does not predict school academic optimism levels; level of trust of secondary and high schools teachers to administrators predicts about school academic optimism levels of their schools. This may be because primary school teachers do not need any other factors for their academic optimism because they are in the classroom environment they form with the students in the classroom. Some research support the results of research on the level of trust in teachers in secondary schools and high schools. Cansoy and Parlar (2018), showed that distributed leadership and trust in the administrator predicted the school academic optimism. Özdemir and Pektaş (2017) also found that there was a positive, significant and moderate relationship between social justice leadership and academic optimism, and that social justice leadership was an important predictor of academic optimism. As a result of Yilmaz and Kurşun (2015) researches, a significant relationship was found between the school principals' instructional leadership behaviors and academic optimism. Hong (2017) found that transformational leadership of school administrators has a positive effect on teachers' academic optimism. Because the academic emphasis on academic optimism is explained by Smith and Hoy (2007) as a focus on establishing an environment based on academic optimism in school for administrators and teachers for student achievement.

The following suggestions can be suggested in the research based on the above results.

*The level of academic optimism of primary schools is higher than that of high schools. The reason for this should be researched and activities should be done to support the schools' academic optimism, to create strong relations with the parents and to improve teachers.

*It is seen that trust in the administrator in secondary and high schools predicts the schools' academic optimism. In this sense, there should be activities based on cooperation and social relations in order to raise the level of trust of teachers in primary schools.

*In addition, organizational justice must be adhered to increase teachers' trust. 
B. Bostanc1, A., \& Bülbül, S. (2018). Do the teachers' organizational trust levels predict their school academic optimism? Journal of Human Sciences, 15(4), 2626-2634. doi:10.14687/jhs.v15i4.5642

\section{References}

Adıgüzelli, Y. (2016). Examining the relationship between distributed leadership and organizational trust according to opinions of teachers. Education \& Science / Egitim ve Bilim, 41(185), 269280.

Ayduğ, D. \& Ağaoğlu, E. (2017). İlkokullarda örgüt sağllğ̣ ile öğretmenlerin örgütsel güven düzeyleri arasındaki ilişki. Anadolu Üniversitesi Eğitim Fakültesi Dergisi, 1(1), 1-17.

Baş, G. \& Şentürk, C. (2011). İlköğretim okulu öğretmenlerinin örgütsel adalet, örgütsel vatandaşl1k ve örgütsel güven alg1ları. Kuram ve Uygulamada Ĕ̈itim Yönetimi, 17(1), 29-62.

Bird, J.J., Wang, C. Watson,J \& Murray, L.(2012).Teacher and principal perceptions of authentic leadership: Implications for trust, engagement, and intention to return.Joumal of School Leadership, 22(3),425-461.

Bostanc1, A.B., Tosun, A. Gidiş, Y. \& Karaca, O.(2016). Öğretmenlerin politik yetileri ile akademik iyimserlikleri ve işe karşı olumlu duygu durumları arasındaki ilişki. 3nd Eurasian Educational Research Congress(08-10 Haziran 2016). Muğla S1tk1 Koçman Üniversitesi, Muğla.

Bökeoğlu, Ö. \& Yılmaz, K. (2008). İlköğretim okullarında örgütsel güven hakkında öğretmen görüşleri. Kuram ve Uygulamada Ë̈itim Yönetimi, 14: 211-233.

Cansoy, R. \& Parlar, H. (2018). Examining the relationships among trust in administrator, distributed leadership and school academic optimism. Kuram ve Uygulamada Eğitim Yönetimi, 24(1), 1-44.

Çağlar, Ç. (2013).Okulların akademik iyimserlik düzeyinin öğretmenlerin örgütsel bağlllı̆̆1 üzerindeki etkisi Mersin Üniversitesi Ë̆gitim Fakültesi Dergisi, 9(1), 260-273.

Çağlar, Ç. (2011). Okullardaki örgütsel güven düzeyi ile öğretmenlerin mesleki tükenmişlik düzeyinin bazı değişkenler açısından incelenmesi. Kuram ve Uygulamada Eğitim Bilimleri Dergisi, 11(4), 1827-1847.

Çapri, B. \& Kan, A. (2006). Öğretmen Kişilerarası Öz-yeterlik Ölçeği’nin Türkçe Formunun geçerlik ve güvenirlik çalışması. Mersin Üniversitesi Eğitim Fakültesi Dergisi, 2(1), 48-61.

Çelik, S. K. \& Gürol, M. (2015) sınıf öğretmenlerinin akademik iyimserlikleri ile yapılandırmacı öğrenme-öğretme etkinliklerini uygulama düzeyleri arasındaki ilişki. Turkish Journal of Educational Studies, 2(2), 1-39.

Dawley, D. D., Andrews, M. C. \& Bucklew, N. S. (2007). Mentoring, supervisor support, and perceived organizational support: What matters most? Leadership \& Organization Development Journal, 29(3), 235-247.

Demirtaş, H. \& Çoban, D. (2011). Okulların akademik iyimserlik düzeyi ile öğretmenlerin örgütsel bağlllığı arasındaki ilişki. Kuram ve Uygulamada Eğitim Yönetimi, 17(3), 317-348.

Demirel, Y. (2008). Örgütsel güvenin örgütsel bağlllık üzerine etkisi: tekstil sektörü çalışanlarına yönelik bir araşturma. Yönetim ve Ekonomi Dergisi, 15(2), 179-19.

Denig, S. J. \& Quinn, T. (2001). Ethical dilemmas for school administrators. The High School Journal, 84(4), 43-49.

Gören, S. \& Özdemir, M.(2015). Ortaokul öğretmenlerinin örgütsel güvene ilişkin görüşlerinin baz1 değişkenlere göre incelenmesi. Mersin Üniversitesi Eğitim Fakültesi Dergisi, 11(3), 264 248.

Hong, Fu-Y.(2017). Antecedent and consequence of school academic optimism and teachers' academic optimism model. Educational Studies Pages, 43( 2), 165-185.

Kalemci Tüzün, İ. (2007). Güven, örgütsel güven ve örgütsel güven modelleri. Karamanoğlu Mebmetbey I.I.B.F. Dergisi, 2: 93-118.

Lam, L. W. \& Lau, D. C. (2012): Feeling lonely at work: Investigating the consequences of unsatisfactory workplace relationships. The International Journal Of Human Resource Management, 23(20), 4265-4282.

Memduhoğlu, H. B.\& Zengin, M. (2011). İlköğretim okullarında örgütsel güvene ilişkin öğretmen görüşleri. YYÜ Eğitim Fakültesi Dergisi, 8 (1) , 211-217. 

Journal of Human Sciences, 15(4), 2626-2634. doi:10.14687/jhs.v15i4.5642

Montani, F., Odoardi, C. \& Battistel, A. (2012). Explaining the relationships among supervisor support, affective commitment to change, and innovative work behavior: The moderating role of coworker support. Bollettno Dı Psicología Applicata, 264, 43-57.

Northfield, S. (2014). Multi-Dimensional Trust: how beginning principals build trust with their staff during leader succession, International Journal of Leadership in Education, 17(4), 410-441.

Özdemir, S \& Kılınç, A. Ç .(2014). Bürokratik okul yapısı ile öğretmenlerin akademik iyimserlik düzeyleri arasındaki ilişki. Journal Of Theory And Practice in Education, 10(1), 1-23.

Özdemir, M. \& Pektaş V. (2017). Sosyal adalet liderliği ve okul akademik iyimserliği ilişkisinin öğretmen görüşlerine göre incelenmesi. Ege Eğitim Dergisi, (18) 2, 576-601.

Özer. N, Demirtaş, H., Üstüner, M. \& M Cömert(2006). Ortaöğretim öğretmenlerinin örgütsel güven algilar1. Ege Eğitim Dergisi, 7(1), 103-124.

Polat, S.(2007).Ortä̈gretim ögretmenlerinin örgütsel adalet algzlar, örgütsel güven düzeyleri ile örgütsel vatandaşlık davranıslar arasındaki ilişki (Yayımlanmamış Doktora Tezi). Kocaeli Üniversitesi, Sosyal Bilimler Enstitüsü. Kocaeli.

Polat, S.\& Celep, C.(2008). Ortaöğretim öğretmenlerinin örgütsel adalet, örgütsel güven, örgütsel vatandaşlık davranışlarına ilişkin algıları. Educational Administration: Theory and Practice, 54: 307-331.

Smith, P. A. \& Hoy, W. K. (2007). Academic optimism and student achievement in urban elementary schools. Journal of Educational Administration, 45(5), 556-568.

Trace, N.E. L.(2016). The relationship among teacher job satisfaction, trust in the principal, and principal support (Dissertations, theses, and masters projects. Paper 1463413079). http://dx.doi.org/10.21220/W47P4X

Winstanley D. \& Stuart- Smith, K. (1996). Policing performance: The ethics of performance management. Personnal Review. 25(6), 66-84.

Yıldırım F. \& İlhan, İ.Ö. (2010). Genel Öz Yeterlilik Ölçeği Türkçe Formunun geçerlilik ve güvenilirlik çalışmas1. Türk Psikiyatri Dergisi, 21(4), 301-308.

Yılmaz, E. \& Kurşun, T. A. (2015).Okul müdürlerinin öğretimsel liderlik davranışları ile öğretmenlerin akademik iyimserlik düzeyleri arasındaki ilişki. Căğdaş Yönetim Bilimleri Dergisi, 1(1), 35-48. 